И. С. Ярышева

Петрозаводск

DOI:10.15393/j9.art.2011.319

\section{РЕЛИГИОЗНАЯ ЖИЗНЬ СЕМЬИ ДОСТОЕВСКИХ (1867-1881) В МЕМУАРАХ А. Г. ДОСТОЕВСКОЙ}

И

зучение творчества Ф. М. Достоевского в контексте христианской духовности имеет более чем столетнюю историю. Тема религиозных убеждений писателя затрагивалась еще его современниками (Вл. Соловьевым, К. Леонтьевым). В начале XX века она бурно обсуждалась в работах представителей русского религиозно-фиилософрского ренессанса (Д. С. Мережковского, С. Н. Булгакова, В. В. Розанова, Н. А. Бердяева, Н. О. Лосского, В. В. Зеньковского, митрополита Антония Храповицкого и др.). Не утратила она своей остроты и сегодня. Современная интерпретация темы «Достоевский и Церковь» представлена в работах о. Димитрия Григорьева, В. Н. Захарова, А. Е. Кунильского, В. М. Лурье, А. М. Любомудрова и многих других исследователей творчества писателя.

«Ты, единственная изъ женщинъ, которая поняла меня!» ${ }^{1}$ - эти слова о том, что для него было важнее всего, Достоевский адресовал самому близкому и преданному ему человеку, супруге Анне Григорьевне. Благодаря ей последние и самые плодотворные 14 лет жизни (1867-1881) он прожил счастливо - любовь, ласка, внимание, забота, тер-

(С) Ярышева И. С., 2011

1 Достоевская А. Г. Воспоминания [1911-1916]. РГБ, 93.III.1.1, л. 4. Далее ссылки на это издание даются в тексте в скобках с указанием названия (В) и листов. пение и понимание со стороны супруги компенсировали ему все тяготы бытия. Но самое главное - она стала незаменимой помощницей в творческой работе мужа как профрессиональная стенографистка, первая слушательница и первый критик его произведений. Свою семейную жизнь с нею писатель связывал с мыслью о покровительстве Божием. В одном из писем, адресованных жене, он писал:

Мнъ Богъ тебя вручилъ, чтобъ ничего изъ зачатковъ и богатствъ твоей души и твоего сердца не пропало, а напротивъ чтобъ богато и роскошно, взросло и разцвьло; далъ мнь тебя, чтобъ я свои грђхи огромные тобою искупилъ, представивъ тебя Богу, развитой, направленной, сохраненной, спасенной отъ всего что низко и духъ мертвитъ... ${ }^{2}$

С целью обнаружить ответ на вопрос, какими видела взаимоотношения Достоевского с Церковью его супруга, обратимся к изображению религиозной жизни семьи Достоевских в ее мемуарах. Это произведения, признанные исследователями жизни и творчества писателя наиболее достоверными фрактографическими источниками о нем: ее «Дневник» 1867 года и «Воспоминания», беловой автографр которых готовился в период с 1911 по 1916 год.

Необходимо иметь в виду, что два указанных мемуарных произведения А. Г. Достоевской по своему характеру различны. Дневник 20-летней девушки, записи в котором велись в первый год замужества, является пред-текстом «Воспоминаний» и отличается до-литературной спонтанностью. Это сумбурные, порой детски непосредственные стенографические записи происшествий и мыслей, приватный и интимный документ, куда заносилось буквально все, беспорядочно и без цензуры разума ${ }^{3}$. Совсем дру-

2 Достоевский Ф. М. Письмо к Достоевской А. Г. От 5 (17) мая 1867 г. РГАЛИ, 212.1.23, л. 7 об.

${ }^{3}$ Из четырех стенографических книжек-тетрадей «Дневника» 1867 года не сохранилось последней, четвертой. Первая из них существует в двух вариантах - стенографическом и расшифрованном через 30 лет А. Г. Достоевской (с литературной правкой). Вторая тетрадь сохранилась лишь в расшифрованном А. Г. Достоевской виде. Первую и третью тетради расшифровала, хотя не бесспорно и не полностью, Ц. М. Пошеманская. Здесь, при необходимости использования цитат из первой тетради 
гое - литературные воспоминания 70-летней вдовы великого писателя, когда у самой мемуаристки окончательно оформился взгляд на Достоевского как на личность, что и определило отбор фрактов для текста «Воспоминаний».

Религиозный образ самой А. Г. Достоевской в обоих мемуарных документах статичен: она предстает воцерковленным человеком. В «Воспоминаниях» Достоевская подчеркивает свое христианское воспитание. В одной из глав пишет с восхищением о матери - шведке по происхождению, лютеранке, принявшей православие:

Сдълавшись православной, моя мать стала ревностно исполнять обряды церкви, говьла, причащалась, но слав<янскіе> молитвы на славянскомъ языкь ею трудно усвоивались и она молилась по шведскому молитвеннику. Она никогда не раскаявалась въ томъ, что перемьнила религію, «иначе, говорила она, я бы чувствовала себя далекою оть мужа и дьтей, а это было бы мнъ тяжело» (В, л. 11-12).

«Строгой исполнительницей обрядов православной церкви» (В, л. 517) Анна Григорьевна стала по примеру отца и «съ истиннымъ удовольствіемъ присутствовала на богослуженіяхъ, особенно на всенощной службъ, когда въ темномъ храмь такъ красиво и таинственно мерцали многочисленныя цвътныя лампады» (В, л. 44). Еще в юности, 13-летней девочкой, она намеревалась уйти в монастырь. «Это быль міръ, который влекъ къ себь мою душу», писала мемуаристка (В, л. 44). Заметим, что именно отец возил Анну Григорьевну на остров Валаам, так очаровавшее ее место, где богомольная девушка наверняка посещала древнюю иноческую обитель, называемую Северным Афоном. Вспоминая о встрече с одним из своих «посватанных женихов», она писала:

Особенно сблизила насъ бесьда о Валаамъ, гдъ онъ тоже бывалъ. Онъ разсказалъ многіе эпизоды своего пребыванія на островђ, я тоже подълилась своими воспоминаніями о знакомыхъ и ему и мнъ тамошнихъ обитателяхъ (В, л. 34 об.).

Судя по дневниковым записям, молодая жена Достоевского, пребывая за границей, регулярно посещает службы

«Дневника» 1867 года, приоритет будет отдаваться записям, расшифрованным самой А. Г. Достоевской и хранящимся в архиве РГАЛИ. в русских церквях и с непосредственностью юной девушки расстраивается, когда это не удается:

Сегодня я собиралась идти в церковь, но из-за бизы не пошла, и мне это так больно; мало того, что я так давно не была в церкви, я дала себе слово непременно идти в это воскресенье, и вот не пошла; но в будущее воскресенье я пойду непременно ${ }^{4}$.

Такие случаи непосещения церкви в воскресные дни 1867 года для Анны Григорьевны крайне редки. Более того, согласно наивным дневниковым записям молодой супруги, сам Федор Михайлович не только не поощряет такой воцерковленный образ жизни жены за границей, но даже прямо или косвенно выступает препятствием ее желанию посетить службу.

Ходила в церковь молиться, а сначала поссорилась с Федей, который меня бранил, зачем я его раньше разбудила (ДН-2, c. 386).

Сегодня я встала рано чтобы идти въ Русскую Церковь. Өедя просилъ меня заварить ему чаю, но Ида какъ нарочно такъ долго копалась съ кипяткомъ, что я просто боялась придти къ концу объдни ${ }^{5}$.

Я сегодня хотьла идти въ русскую Церковь, но случилось такъ, что я, заснувъ въ 12 часовъ ночи, была разбужена Өедею въ 2 и съ этой минуты уже никакъ не могла заснуть (ДН-1, Л. 193).

Я пришла домой из церкви довольно веселая, но меня встретил Федя сурово и указал на произведенный беспорядок в доме (ДН-2, с. 75).

Сегодня я хотела идти в церковь, но Федя сказал, что это можно и отложить и я осталась (ДН-2, с. 108).

Сегодня я встала довольно рано и, когда Өедя проснулся, спросила его, можно-ли мнъ идти въ церковь. Онъ согласился, я поскорье одьлась и ушла (ДН-1, л. 62).

${ }^{4}$ Достоевская А. Г. Дневник 1867 года. М., 1993. С. 347-348 (стенограф. запись в расшифровке Ц. М. Пошеманской). Далее ссылки на это издание даются в тексте в скобках с указанием названия (ДН-2) и страниц.

5 Достоевская А. Г. Дневник 1867 года. Книга 1 // РГАЛИ, 212.1.148. Л. 225 (стенограф. запись в расшифровке А. Г. Достоевской). Далее ссылки на это издание даются в тексте в скобках с указанием названия (ДН-1) и листов. 
Как указывает Н. О. Лосский, связь жены Достоевского с церковью «сохранялась всегда в традиционных формах. По праздничным и воскресным дням она, обыкновенно, ходила в церковь, тогда как из сведений, имеющихся о Достоевском, скорее видно, что он сравнительно редко бывал в церкви, по крайней мере до возвращения в Россию из-за границы в 1871 г.»6. Судя по записям «Дневника» 1867 года, действительно, упоминание о совместном посещении супругами Достоевскими православного храма единично:

Мы заходили въ Русскую церковь Николая Чудотворца на Большой улиць, поклониться Плащаницъ (ДН-1, л. 3).

Это было в городе Вильна в апреле 1867 года, в самом начале заграничного путешествия Достоевских. При этом интересно отметить, что записи о совместном посещении путешествующими супругами католических и протестантских церквей, описание их архитектурных особенностей в «Дневнике» встречаются гораздо чаще. Как известно, Ф. М. Достоевский интересовался памятниками церковной архитектуры. Особое его внимание привлекала готика, неслучайно рукописи писателя изрисованы элементами готических соборов. Такой же интерес он хотел привить своей юной жене:

Федя (увидев старинную готическую церковь - И. Я.) <...> началь бранить меня зачъмъ я разговариваю со старухами, а не обратила вниманія на это совершенство въ искуствђ. Онъ быль не правъ: я ее очень хорошо разсмотръла; дъйствительно Церковь удивительно хороша, оригинальной архитектуры (ДН-1, л. 97-98).

Семейный быт Достоевских включал обсуждение разных, в том числе и религиозных, вопросов:

Потом вечером у нас обыкновенно идут разговоры; так, вчера мы говорили о евангелии, о Христе, говорили очень долго (ДН-2, с. 275).

Размеренная жизнь вне суеты и проблем Петербурга, возможность спокойного обдумывания творческих замыслов и, конечно, душевная семейная обстановка — все это было существенным фактором религиозной жизни писателя.

${ }^{6}$ Лосский Н. О. Бог и мировое зло. М., 1994. С. 56.
По справедливым наблюдениям Ю. И. Айхенвальда, в частых семейных конфрликтах в начале семейной жизни Достоевских, отраженных в «Дневнике» А. Г. Достоевской, «нависавшая гроза и тревога разрышалась счастливо» ${ }^{7}$. Дальнейшая жизнь с доброю и умною женою, понимавшею величие гения своего мужа и прощавшею ему его недостатки, принесла такие глубокие переживания, которые создали «неразрывное сочетание двух душ» ${ }^{8}$.

В «Воспоминаниях» религиозная жизнь Достоевского предстает более насыщенной, чем в «Дневнике» юной девушки. Здесь, в оправдание столь нечастого посещения мужем церкви, мемуаристка указывает на его распорядок дня, вызванный всегдашней необходимостью работы на износ. Достоевский, как в России, так и за границей, работал обычно ночью, вставал поздно.

Өеодоръ Михайловичъ любилъ порядоњъ во всемъ, въ томъ числь и въ распредњленіи своего времени; поэтому у насъ вскоръ установился строй жизни, который не мъшаль никому изъ насъ пользоваться временемъ какъ мы хотъли. Такъ какъ мужъ работалъ ночью, то вставалъ не раньше один $<\mathrm{H}>\mathrm{a}$ дцати. Я съ нимъ завтракала и тотчасъ отправлялась осматривать какую нибудь Sammlung и въ этомъ случађ моя молодая любознательность была вполнь удовлетворена (В, л. 185).

На Страстной неделе Достоевский, как вспоминала его супруга, вместе с семьею постился, ходил два раза в день в церковь и причащался:

Могу удостовърить, что на всњ великія службы Страстной и Пасхальной недъль мы ходили съ мужемъ всегда вмъсть (я боялась не произошло-бы (отъ духоты и тьсноты) припадка), и бывали или въ правомъ предъль Знаменской Церкви, а въ посльдніе три года - во Владимірской Церкви (В, л. 735).

К тому же интерес к готической церковной архитектуре, отмеченный его женою в дневниковых записях, не был основным для Достоевского. В «Воспоминаниях» Анна Григорьевна указывает, что муж «чрезвычайно цьнилъ архитектуру» жемчужины московского барокко, символа высокого развития русской церковной архитектуры - «церкви

\footnotetext{
${ }^{7}$ Айхенвальд Ю. И. Две жены: Толстая и Достоевская. Берлин, 1925. C. 148.

8 Лосский Н. О. Указ. соч. С. 15
} 
Успенія Божіей Матери (что̀ на Покровкъ)» «и, бывая въ Москвъ, непремънно ьхалъ на нее взглянуть» (В, л. 156). Как впоследствии рассказывала Е. П. Достоевская, опираясь на слова Анны, вдовы писателя, Достоевский «ходил преимущественно в простые, уединенные церкви, любил деревенские церкви и его любимым духовником был о. И. Румянцев в Старой Руссе» 9 .

Религиозный быт мемуаристки был неизменен до конца ее дней. Невестка Анны Григорьевны Екатерина Петровна Достоевская вспоминала о жизни свекрови в 1917 году:

Каждый вечер неизменно я сквозь запертые двери слышала ее полусдержанный голос, повторявший молитвы, - голос горячей мольбы, убеждения, надежды, порою слезы; так молиться может человек, у которого никогда и тени сомнения не зарождалось, который опять-таки верил слепо, без рассуждений. Анна Григорьевна осуждала и возмущалась мистикой или спиритическими воззрениями - она находила, что можно верить или так, как повествует Евангелие, или не верить вовсе ${ }^{10}$.

Федор Михайлович, в отличие от супруги, обретал веру путем мучительно-целительных сомнений. «Жаждешь, как “трава иссохшая”, веры и находишь ее, собственно, потому, что в несчастье яснеет истина», - писал он Н. Д. Фонвизиной в феврале 1854 года ${ }^{11}$. И это отличие в их способах обретения веры известно Достоевской. Мемуаристка не решается погружаться в глубины сложнейшей духовной и творческой жизни писателя. Однако несправедливы и обвинения К. И. Чуковского следующего содержания:

В ея благоговъйном воображеніи он рисуется каким-то простым и уютным обывательским дядей без всяких сатанинских соблазнов и без всяких мучительных противорьчій ${ }^{12}$.

Анна Григорьевна и в этом отношении старается быть объективной. Так, рассказывая о замысле нового романа мужа «Житие великого грешника", Достоевская отмечает:

\footnotetext{
${ }^{9}$ Волоцкой М. В. Хроника рода Достоевского (1506-1933). М., 1933. C. 154 .

${ }^{11}$ Достоевский Ф. М. Полн. собр. соч.: В 30 т. Л., 1985. Т. 28. Кн. 1. C. 176 .

${ }^{12}$ Сперанский В. Н. Вдова Достоевскаго. К 70-летию смерти писателя. Страница воспоминаний // Русский мир. 1951. № 318 (9 февраля).
}

Во всъхъ пяти повъстяхъ Өеодоръ Михайловичъ предполагалъ провести тотъ важный и мучительный вопросъ, которымъ онъ больлъ всю свою жизнь, именно вопросъ о существованіи Бога (В, л. 233-234).

Особое внимание в «Воспоминаниях» уделяется молитве Достоевского - интимному проявлению религиозной жизни. Достоевский любил молиться и всецело отдавался общению с Богом. Об этих минутах жизни мужа Анна Григорьевна рассказывает:

Въ соборъ было не мало народу и служили непрерывные молебны передъ иконой Казанской Божіей Матери. Өеодоръ Михайловичъ тотчасъ скрылся въ толпь. Зная, что въ иныя торжественныя минуты онъ любитъ молиться въ тиши, безъ свидътелей, я не пошла за нимъ и только полчаса спустя отыскала его въ уголк' собора, до того погруженнаго въ молитвенное и умиленное настроеніе, что въ первое мгновеніе онъ меня не призналъ (В, л. 405).

Придумав план устроить поездку за границу, несмотря на недостаток средств, Анна Григорьевна предложила мужу зайти в часовню Вознесенской церкви, и там они «вмњсть помолились передъ образомъ Богородицы» (В, л. 178).

Когда начались роды первого ребенка, Достоевский всю ночь молился, и при появлении на свет дочери Сони он «благоговьйно перекрестилъ» ее (В, л. 216). Перед рождением сына Федора Достоевский молился "весь день и всю ночь» (В, л. 252). Когда двухлетняя дочь Достоевских Любочка сломала ручку, она неправильно срослась и пришлось прибегнуть к операции, Достоевский уповал на помощь Божию:

- Аня, будемъ молиться, просить помощи Божіей, Господь намъ поможетъ! прерывающимся голосомъ сказалъ мнъ мужъ и мы опустились на кольни и, никогда, можеть быть, не молились такъ горячо, какъ въ эти минуты! (В, л. 288).

Воспитанные в христианских традициях Достоевские так же воспитывали и своих детей.

Въ девять часовъ дьтей нашихъ укладывали спать и Өеодоръ Михайловичъ непремънно приходилъ къ нимъ «благословить на сонъ грядущій» и прочитать вмъсть съ ними «Отче Нашъ», «Богородицу» и свою любимую молитву: «Все упованіе 
мое на Тя возлагаю, Мати Божія, сохрани мя подъ кровомъ Твоимъ!» (В, л. 348).

Через четыре года, возвращаясь в Петербург и проезжая мимо собора св. Троицы, «въ которомъ происходило наше вънчаніе... мы съ мужемъ помолились на церковь; на насъ глядя, перекрестилась и наша малютка-дочь» (В, л. 251).

Молитва - религиозный акт, сближающий членов семьи Достоевских с уже покойным Федором Михайловичем:

...я рьшила чтобы по моемъ мужь совершали сорокоусть въ Александро-Невской Лаврь и въ теченіи 40 дней присутствовала вмъстђ съ моими дътьми на заупокойной объднь въ Церкви Св. Духа и на панихидь и литіи на могиль. Это ежедневное посьщеніе могилы $\Theta<$ еодора> $\mathrm{M}<$ ихайловича>, молитва и слезы по немъ сближали насъ съ усопшимъ и мы такимъ образомъ какъ-бы еще нькоторое время не разставались съ нимъ окончательно (В, л. 517).

Истинный христианин проверяется своим поведением перед смертью, которым измеряется его вера в Воскресение и всеблагость Божию.

Но Христосъ воскресъ изъ мертвыхъ, первенецъ изъ умершихъ. Ибо какъ смерть человъкомъ, такъ человькомъ же и воскресеніе мертвыхъ. Какъ Адамомъ всъ умираютъ, такъ Христомъ всь оживутъ ${ }^{13}$.

Сам Достоевский в декабрьском выпуске «Дневника писателя» за 1876 год утверждал:

Право, у нас теперь иной даже молится и в церковь ходит, а в бессмертие своей души не верит, то есть не то что не верит, а просто об этом совсем никогда не думает. <...> А меж тем лишь из этой одной веры, как уже и говорил я выше, выходит весь высший смысл и значение жизни, выходит желание и охота жить ${ }^{14}$.

В так называемом «Альбоме признаний», хранящемся в отделе рукописей Российской государственной библиотеки, есть анкета А. Г. Достоевской, где она на вопрос: «Какою смертью хотьли бы вы умереть?» дала ответ христианки:

\footnotetext{
${ }^{13}$ Первое послание Святого Апостола Павла к Коринфянам. Гл. XV // Евангелие. СПб., 1823. Ст. 20-22. С. 461.

${ }^{14}$ Достоевский Ф. М. Полн. собр. соч.: В 30 т. Л., 1982. Т. 24. С. 50.
}

«Похворавъ и покаявшись» ${ }^{15}$. Спутница писателя умерла после продолжительной болезни 9 июня 1918 года в Ялте, пережив его на 37 лет.

Согласно ее «Воспоминаниям», последние три дня жизни, когда лопнула легочная артерия и начались кровотечения горлом, Достоевский провел спокойно, как твердо верующий православный христианин, с постоянною мыслью о Боге.

«Аня, прошу тебя, пригласи немедленно священника, я хочу исповьдаться и причаститься!» - обратился он к жене после сильного кровотечения. Когда священник пришел,

Өеодоръ Михайловичъ спокойно и добродушно встрьтилъ Батюшку, долго исповьдывался и причастился. Когда священникъ ушелъ и я съ дътьми вошла въ кабинетъ чтобы поздравить Өеодора Михайловича съ принятіемъ Св. Тайнъ, то онъ благословилъ меня и дьтей, просилъ ихъ жить въ мирђ, любить другь друга, любить и беречь меня. Отославъ дътей, Өеодоръ Михайловичъ благодарилъ меня за счастье, которое я ему дала и просилъ меня простить, если онъ въ чемъ нибудь огорчилъ меня (В, л. 480-481).

Через день, проснувшись рано утром, он сказал жене: «Я сегодня умру» и попросил дать ему Евангелие.

Открылось Евангеліе от Матөея. Гл. III, ст. II: «Іоаннъ же удерживалъ его и говорилъ: мнђ надобно креститься отъ тебя и ты-ли приходишь ко мнъ? Но Іисусъ сказалъ ему въ отвътъ: не удерживай, ибо такъ надлежитъ намъ исполнить великую правду».

— Ты слышишь - «не удерживай», значитъ, я умру, сказаль мужъ и закрылъ книгу.

Я не могла удержаться отъ слезъ. Өеодоръ Михайловичъ сталь меня утьшать, успокоивать, говорилъ мнђ милыя, ласковыя слова, благодарилъ за счастливую жизнь, которую онъ прожил со мной. Поручалъ мнъ дътей, говорилъ, что въритъ мнъ и надъется, что я буду ихъ всегда любить и беречь. <...> ...По умиротворенному лицу было ясно видно, что мысль о смерти не покидаетъ его и что переходъ въ иной міръ ему не страшенъ (В, л. 483-485).

В память о муже вдова Достоевского создала церковноприходскую школу его имени в Старой Руссе, стараясь глав-

15 «Альбом признаний» [1889]. РГБ, 93.III.3.2. 
ное внимание в ней обратить «на религіозно-нравственное воспитаніе крестьянскихъ дьтей» (В, л. 578), как мечтал ее муж.

В мемуарах Анны Григорьевны семья Достоевских предстает православной и воцерковленной, а ее глава, Ф. М. Достоевский, таким, каким он был в жизни и творчестве: человеком, выстрадавшим веру, воспитывавшим детей в православных традициях, принявшим христианскую смерть, наконец, писателем, чье творчество непостижимо вне православия. 